Ayurlog: National Journal of Research in Ayurved Science

http://www.ayurlog.com Volume: $6^{\text {th }} \mid$ Issue: $5^{\text {th }} \mid$ August 2018

\title{
An Ayurvedic management of PCOD: A Reviews
}

\section{Ramesh M. Bansode ${ }^{1}$, Supriya Chikhalekar ${ }^{* 2}$}

1. Professor,

2. PG Scholar, Department of Kriya Sharir, Goverment Ayurved College, Nanded.

Department of Kriya sharir, Goverment Ayurved College, Nanded, Maharashtra.

*Corresponding Author: Email: supriyachikhalekar@gmail.com. Mob.: 9403079791

\section{Abstract:}

PCOD can be managed with Ayurvedic diet. Ovarian Syndrome is one of the most common female endocrine disorders affecting approximately $5 \%$ to $10 \%$ of women of reproductive age and is thought to be one of theleading causes of female sub-fertility. The symptoms of PCOS may begin in adolescence with menstrual irregularities, infertility, hig levels of masculinising hormones, metabolic syndromes.In Ayurveda, this condition is not explained as a single disease, but can be under the headings of Yonivyapad and Artavadushti. In this study, elementary books of Ayurveda and modern were searched and analyzed for proper utilization in prevention and cure of PCOS. PCOS is an emerging problem among women leading to endocrine dysfunction.Treatment modalities aim at clearing obstruction in pelvis, treating Agnimandhya at Jatharagni,Dhatwagni level and alleviating Srotoavarodha and ultimately regularizing the Apana Vata. PCOD can be managed with Ayurvedic dietary management.

Keywords: Polycystic Ovarian Syndrome, Yonivyapad, ,jatharagni,dhatwagni

\section{Introduction:}

Polycystic ovarian syndrome is a most prevalent endocrinopathy. Incidence of this disease is increasing now a days because of sedentary lifestyles, pollution, excessive intake of junk food.It is obviously observed in women seeking medical advice for infertility as well as irregular menstrual bleeding, majority of these cases could be treated either by hormonal therapy or surgical intervention ,this study will emphasize on careful management of polycystic ovarian syndrome.Polycystic ovarian syndrome is a *ondition where a hormonal imbalance affects follicular growth during the ovarian cycle causing the affected follicles to remain in the ovary $^{1}$

Diseases of longevity often referred as "lifestyle disorders" are posing a great threat to the overall health of the Society.Twenty diseases of the vagina arises because of consuming bad food by ashtang hridayam. The PCOD is one of the most frequent endocrine disease in women of reprductive age with a prevalence of $9.13 \%$ in Indian population ${ }^{2}$

.It is characterized by Hyperandrogenism and chronic anovultion. ${ }^{3}$

As PCOD is associated with hyperisulinemia it has major metabolic as well as reproductive morbidities . ${ }^{4}$

The modern medicine has been able to pinpoint a number of important factors indicating the disease determinants however 
the exact cause of the disease is unknown .PCOS is the condition where a hormonal imbalance affects follicular growth during the ovarian cycle causing the affected follicles to remain in the ovary. The retained follicle forms in to a cyst and with each ovarian cycle a new cyst is formed leading to multiple ovarian cysts. In ayurveda this condition is not explained as a single disease entity, but given under the headings yonivyapada(genital disorders) and artavadushti(menstrual disorders).PCOS there is nashtaartava, which means loss of both menstruation as well as ovultion. $^{5}$ In modern science they focus on obesity giving hormonal pills as a treatment's in medicinal therapy which has various side effects . So the objective of this article is to provide better treatment through Ayurveda.

\section{Etiology:}

In the context of yonivyapadas, there are four basic causative factors i.e. unwholesome lifestyle, menstrual disarrays (dushti of ova and bahipushpa i.e. menstrual blood), geneti disorders and some divine factors responsible for the manifestation of the syndrome.It is a disorder involving vata and kapha ${ }^{7}$ doshas along with Meda Dhatu dushti ${ }^{8}$. On the basis of Ayurvedic interpretation PCOS can be enumerated as Rasapradoshaja ${ }^{9}$ and santarpanottha vyadhi ${ }^{10}$

Ahara and vihar causing vatakaphadushti and medodushti, will be the key factors causing the expression of the syndrome. Genetic and environmental contributors to hormonal disturbances combine with other factors, including obesity ovarian dysfunc-tion, and hypothalamic pituitary abnormali-ties to contribute to the aetiology of PCOD. Obesity increases hyperandrogen-ism, hirsutism, and infertility and pregnancy complications independently and by exacerbating PCOD.

\section{Pathophysiology:}

Kaha is dominated in PCOD leading to amenorrhoea as when apana is influenced by pitta it creates artavatipravrit-ti ${ }^{11}$. The main cause is Vishama aahar vihar which leads to agnimandya and leading to drushti of ras dhatu as well as aartava and also causes kaphavridhi which further leads to srotorodhajanya apachita-medodhatuvridhi and vataprakopa causing obesity and amenorrhoea.The exact pathophysiology is not clearly un-derstood. It may be discussed as hypotha-lamic pituitary compartment abnormality, androgen excess, anovulation, obesity and insulin resistance.

The clinical features according to modern can be categorized as

Ovulatory and menstrual dysfunction: anovulation, oligomenorrhoea or irregular vaginal bleeding

1) Clinical features of hyperandrogenism: hirsutism, acne, androgenic alopecia.

2) Polycystic ovariesAs evidenced by radiological findings

\section{Ayurvedic management}

In Ayurveda ,the management PCOD should concentrate on treating Agnimandhya at Jatharagni and Dhatwagni level and alleviating srotavarodhana and ultimately regulating the Apana Vata So, Ayurvedic protocol for PCOD includes

1) Shodhan chikitsa

2) Shaman chukicha

\section{1) Shodhan chikitsa}

Includes Panchakarm upachar especially basti in conditions of Vata. Other Panchkarma modalities Vamana (emesis), Virechana (purga-) are also prescribed for vitiated Kapha Pitta respectively. Snehana (oleation) Swedana (sudation) to be Chikitsa . 
2) shaman chikitsa-Ayurveda has wide range of medicines to give strength to ovarian function.

a. The management approach to PCOS concentrate on treating Agni- mandya at jatharagni and dhatwagni level and alleviating srotovarodham and regularizing the apanavata. Amapachan and agnideepana through chitrakadivati/ panchkolachurna.

b. Pathadikwatha described by sushruta in when given orally with satapushpa tail matrabasti for seven days after cessation of menstruations is found to be effective. Aampachan, srotoshodhan and vatakaphashamakproperties may be responsible for efficacy kumaraghrita described by acharya-vagbhata reduces the size of ovarian cyst $^{12}$

c. Satapuspachurna: dipanapachana, and helps ovulation, is the drug of choice in an disease vatakaphashamak, pitttavardhaka, due to its katu,tikta rasa, ushna- and tikshana,snigdha,guna. ${ }^{13}$

d. Narayan tail:With its katutikta rasa, laghu, rukshaguna, usnavirya, katuvipaka, vatakaphashamak and ultimately leads to such as deepan , pachana, vilayan, anuloman and srotoshodhan resulting in aampachan and vatakaphashamak which removes sanga and aavarana lead-ing to proper function of vayu regulating karma resulting in bijotsar-(ovulation.) ${ }^{14}$

e. Use of various lekhandravyas like takra, as described by acharyacharak along with lifestyle modification of medovridhhi. Dietary modifications are also useful.

f. Dincharya of the patients should be adjusted to that described in ayurveda as far as possible. g. Yoga and pranayam therapypranayam,kapalbahti,suryanamskar,

\section{Discussion:}

PCOD is an upcoming problem in gynaecology OPD. The first step done in general practice in OPD's when a patient $\mathrm{OF}$ PCOD comes is to advise weight reduction.

Weight reduction in obese patient is the intial recommendation because it reduces insulin, and androgen levels and may restore ovulation. The treatment modalities at providing comprehensive care by corresponding the ama dosha( insulin levels), achieving koshta shuddhi and regulating tridosha, by this the menstruation is regularized and fertility is restored.

\section{Conclusion:}

PCOD is life style disorder and leading cause of women in reproductive age group leading to endocrine dysfunction and multiple sign and symptoms.

In treating PCOD we should consider the presentation and extent of pathogenesis. Treatment of women affected by PCOD needs a balanced diet,pranayam,yoga,shaman,shodhan chikitsa ,stress free lifestyle

\section{References:}

1. The infertility manual by Kami A Rao , Chapter no.10,page no.110 ,Edition 2009

2. Ram Nidhi, venkatrampadmalatha, raghuramnagarathna, ram amritanshu: prevalence of polycystic ovarian syndrome in Indian adolscents journal of paediatric and adolescent gynecology, volume 24, issue 4, august 2011.

3. Frank S 1995 polycystic ovarian syndrome, N Engl J Med 333:853861 
4. Burghen GA, Givens J, Kitabchi AE 1980 correlation of hyperandrogenism with hyperinsulinism in polycystic ovarian disease. J. Clin Endocrinol Metab 50:113-116

5. Tripathi Brahmananda hindi commentary, Chaukhamba Surbharti Prakashana,,Varanasi, 2006; Charaka samhita Chikitsasthana 28/15-19,page no. $937-938$

6. Shastri PK \& Chaturvedi GN; Charaka Samhita, Vidyotini hindi commentary, Chikitsasthana 30/08; Chaukhamba Sanskrit Sansthana, Varanasi; reprinted ed -2012; p-841

7. Dalhana; Sushruta Samhita, Nibandh Sangraha and Nyaya Chandrika commentary, editor Jadavji $\mathrm{T}$, Sharirasthana 2/4; Chaukhamba Sanskrit Sansthana, Varanasi; ed 2014; p- 344

8. Shastri PK \& Chaturvedi GN; Charaka Samhita, Vidyotini commentary, Sutrasthana
Chaukhamba Sanskrit Sansthana, Varanasi; reprinted ed -2012; p-572

9. Charak samhita sutra sthan $28 / 9-10$ page no. 571

10. Charak samhita sutra sthan $23 / 5,6,7$ page no. 436

11. Vagbhata, AsthangHridya, edited by Atrideva Gupta, reprint ed., ChaukhambaSanskritaSansthan Varanasi, 2006:Nidanasthana16/45.

12. Patel KD, Del L, Donga SB, Anand N, Effect of Satpuspa Tail MatraBasti and PathadiKwath on polycystic ovarion diseaseAYU [serial online] 2012 [cited 2013 Aug 23];33:243

13. Vridhajivak, Kasyapasamhita, edited by Prof. P.V. tiwari, 1st edition, ChaukhambaVishwabharti,Varanasi, 1996: Kalpasthana, 5/23, page no. 161.

14. Donga S.B, Effect of Narayan Tail Nasya And Matrabasti in Anovulatory Cycle AYU [serial online] 2011; 23. 